\title{
PENYEBAB ECONOMIC EXPOSURE PADA PERUSAHAAN MANUFAKTUR GO PUBLICDI BURSA EFEK INDONESIA
}

\author{
Zulki Zulkifli Noor \\ Universitas Winaya Mukti \\ Jalan Pahlawan No. 69 Bandung \\ e-mail: Ake_zulkifli@yahoo.com
}

\begin{abstract}
ABSTRAK. Tujuan penelitian ini adalah untuk mengetahui faktor-faktor yang mempengaruhi economic exposure dan faktor yang dominan pengaruhnya terhadap economic exposure pada perusahaan-perusahaan yang go public yang berada dalam kelompok perusahaan manufaktur. Ada lima faktor yang diteliti berdasarkan hubungan yang erat dengan fluktuasi kurs terutama USD yang merupakan mata uang yang lebih mendominasi dalam transaksi internasional di Indonesia, yaitu status perusahaan, kewajiban bersih valuta asing, prosentase ekspor terhadap total penjualan, impor bahan baku dan bahan pembantu, dan pelaksanaan hedging atas fluktuasi kurs. Analisa multivariate digunakan untuk melihat kelima faktor di atas terhadap economic exposure. Sebelum dilakukan analisa multivariate, terlebih dahulu dilakukan analisa univariate yang berguna untuk menguji setiap variabel yang digunakan. Berdasarkan penelitian ini, dapat diambil kesimpulan sebagai berikut : (1.) Kelima faktor tersebut mempengaruhi economic exposure di $62 \%$, 38\% lebih banyak dipengaruhi oleh faktor lain di luar faktor yang diteliti. (2.) Faktor yang dominan pengaruhnya terhadap economic exposure adalah kewajiban bersih valuta asing, karena memiliki nilai yang signifikan terhadap economic exposure.
\end{abstract}

Kata Kunci : Kewajiban bersih valuta asing, prosentase ekspor terhadap total penjualan, impor bahan baku dan bahan pembantu, pelaksanaan hedging atas fluktuasi kurs, economic exposure.

\section{ECONOMIC EXPOSURE CAUSES IN GO PUBLIC MANUFACTURING COMPANIES IN INDONESIA STOCK EXCHANGE}

ABSTRACT. The purpose of this study to determine the factors that affect economic exposure and the major influences on economic exposure to companies that go public in the manufacturing company. There are five factors studied on the basis of a close relationship with the fluctuation of exchange primarily USD, which is the dominant currency in international transactions in Indonesia, the fifth company status, the net liabilities denominated in foreign currencies, the percentage of exports to total sales, imports of raw materials and auxiliary materials, and implementation of hedging for exchange rate fluctuations. Multivariate analysis is used to view the five factors of economic exposure. Before multivariate analysis, first conducted univariate analysis that is useful to examine each of the variables used. Based on these results, it can be concluded as follows: 
(1.) The five factors that affect economic exposure under $62 \%, 38 \%$ more influenced by other factors beyond the factors studied. (2.) Major factors affect the economic exposure is the net foreign currency liabilities, because it has significant value to economic exposure.

Keywords: net liabilities denominated in foreign currencies, the percentage of exports to total sales, imports of raw materials and auxiliary materials, implementation of hedging for exchange rate fluctuations, economic exposure.

\section{PENDAHULUAN}

Economic exposure ini diteliti karena saat ini perubahan lingkungan eksternal sangat cepat berubah, sehingga pefubahan fluktuasi kurs sangat cepat, sehingga Pemerintah dalam hal ini Bank Indonesia harus mengendalikan faktor penyebab perubahan tersebut agar nilai tukar rupiah tidak anjlok terlalu besar, hal ini sejalan dengan terjadinya integrasi secara global dari barang dan jasa yang memaksa suatu negara untuk dapat menspesialisasikan dirinya dan meningkatkan efisiensi penggunaan sumber daya manusia maupun alamnya yang merupakan akibat dari meningkatnya perdagangan internasional dan investasi internasional yang diikuti peningkatan lalu lintas komunikasi dan transportasi serta usaha antar negara untuk menurunkan hambatan dan tarif.

Transaksi ekspor dan impor yang dilakukan di Indonesia menggunakan berbagai mata uang asing. US Dollar (selanjutnya disingkat USD) merupakan mata uang yang paling sering digunakan dalam transaksi ekspor dan impor di Indonesia. Pengaruh perubahan kurs setiap perusahaan tentunya tidak sama, tergantung dari strategi dan kebijakan yang diambil perusahaan.

Perubahan kurs valuta asing berpengaruh pada arus kas perusahaan, baik perusahaan tersebut melakukan transaksi dengan pihak luar negeri ataupun hanya melakukan transaksi dengan pihak dalam negeri. Pengaruh fluktuasi valuta asing terhadap perusahaan atau disebut foreign exchange exposure dapat dikelompokkan dalam 3 bentuk, yaitu transaction exposure, operating exposure, dan translation exposure. Economic exposure timbul karena fluktuasi kurs mata uang yang nantinya dapat mempengaruhi nilai ekonomis perusahaan. Nilai ekonomis perusahaan yang dipengaruhi adalah pendapatan dan biaya perusahaan atau operating cash flomnya di masa yang akan datang. Untuk itu penelitian ini ingin melihat seberapa besar faktor-faktor yang mempengaruhi economic exposure US Dollar dari perusahaan-perusahaan go public yang berada dalam kelompok perusahaan menufaktur yang listing di Bursa Efek Indonesia.

Sejalan dengan permasalahan di atas, tujuan dari penelitian ini adalah :

1. Untuk mengetahui besarnya nilai faktor-faktor yang mempengaruhi economic exposure dari tahun 1999 hingga tahun 2003 pada perusahaan-perusahaan go public yang berada dalam kelompok perusahaan manufaktur. 
2. Untuk mengetahui faktor-faktor yang paling besar pengaruhnya terhadap economic exposure USD pada perusahaan - perusahaan go public yang berada dalam kelompok perusahaan manufaktur.

\section{Referensi yang relevan}

Economic Exposure

Pengelolaan economic exposure dengan mengubah kebijakan operasi perusahaan yang umum digunakan adalah melakukan leads (mempercepat pembayaran) atau lags (memperlambat pembayaran), melakukan risk sharing, yaitu suatu perjanjian yang mana pembeli dan penjual setuju untuk membagi dampak pergerakan mata uang atas pembayaran yang terjadi diantara mereka, dan menggunakan reinvoicing center, yaitu suatu subsidiary terpisah pada suatu lokasi yang khusus mengelola seluruh transaction exposure dari perdagangan yang terjadi antar subsidiary atau dengan parent companyya.

Pengelolaan economic exposure dengan merubah kebijakan keuangan perusahaan biasanya meliputi : Penggunaan natural hedge dengan melakukan matching aliran kas mata uang, Back to back loans atau parallel loans, dan Currency Swaps.

\section{Perilaku Nilai Tukar}

Setiap perusahaan harus mempelajari perilaku nilai tukar, system nilai tukar yang dianut suatu negera, dan pengaruh nilai tukar terhadap harga saham yang merupakan cerminan dari nilai perusahaan, sebab dengan pengetahuan tersebut, perusahaan dapat menentukan pengelolaan exposure yang tepat dala mengalami fluktuasi nilai tukar dan dapat mengambil keputusan yang tepat demi kelangsungan bisnis perusahaan.

Menurut Eiteman $(1995,129)$, perusahaan biasanya melakukan peramalan nilai tukar untuk salah satu tujuan, yaitu accounts payable and receivable, international price lists, working capital management, dan international investment analysis.

\section{Bisnis Internasional}

Menurut Jeff Madura (1997;457), ada beberapa kemungkinan motif bagi perusahaan untuk melakukan bisnis internasional, yaitu attrack new sources of demand, enter markets where superior profits are possible, fully benefit from economic of scale, use foreign factors of production, use foreign raw materials, exploit foreign technology, exploit monopolistic advantage, diversify internationally, react to a foreign currency's changing value, react to trade restrictions, dan benefit politically.

Kemungkinan suatu hasil yang kurang menguntungkan dibanding yang di harapkan sering diartikan sebagai resiko. Bagi perusahaan yang melakukan bisnis internasional dihadapkan pada resiko yang lain yang dapat berbentuk unsystematic risk, artinya resiko yang dapat didiversifikasikan, namun ada juga yang berbentuk systematic risk, yaitu resiko yang tidak dapat didiversifikasikan. Abuaf (1988) membedakan resiko internasional menjadi dua, yaitu foreign-exchange exposure 
risk dan political risk (Abuaf; 1988;3). Sedangkan Alan C. Saphiro (1996) memfokuskan resiko internasional pada inflation risk, exchange risk, dan political risk (1996; 23).

\section{Resiko Valuta Asing}

Pengaruh resiko valuta asing terhadap perusahaan atau disebut foreign exchange exposure dapat dikelompokkan dalam tiga bentuk, yaitu Transaction exposure yang timbul karena perusahaan melakukan transaksi/kontrak dalam valuta asing dan pada saat terjadi perubahan nilai tukar, kontrak tersebut belum selesai, Operating exposure yang timbul karena fluktuasi nilai tukar dapat merubah pendapatan dan biaya perusahaan, yakni operating cash flownya, dan Translation exposure adalah exposure dari laporan keuangan konsolidasi MNC akibat perubahan nilai tukar.

\section{Faktor-Faktor yang Mempengaruhi Economic Exposure}

Faktor-faktor yang dapat mempengaruhi economic exposure adalah (Alan Saphiro, 1996):

a. Penjualan produk perusahaan, dalam negeri atau luar negeri.

b. Pesaing utama perusahaan, perusahaan dalam negeri atau luar negeri.

c. Elastisitas permintaan barang terhadap harga.

d. Lokasi produksi perusahaan, dalam negeri atau luar negeri.

e. Impor bahan baku dan bahan pembantunya atau tidak.

f. Penetapan harga input atau outputnya, ditetapkan berdasarkan harga pasar dunia atau pasar domestik dan menggunakan mata uang apa.

g. MNC atau bukan MNC.

h. Hutang dalam mata uang apa.

i. Hedging atau tidak hedging.

j. Penggunaan mata uang.

Economic exposure dipengaruhi oleh beberapa faktor, yaitu Penjualan produk perusahaan, dalam negeri atau luar negeri, .Pesaing utama perusahaan, perusahaan dalam negeri atau luar negeri, Elastisitas permintaan barang terhadap harga, Lokasi produksi perusahaan, dalam negeri atau luar negeri, Impor bahan baku dan bahan pembantunya atau tidak, Penetapan harga input atau outputnya, ditetapkan berdasarkan harga pasar dunia atau pasar domestik dan menggunakan mata uang apa, MNC atau bukan MNC, Hutang dalam mata uang apa, Hedging atau tidak hedging, serta Penggunaan mata uang (Alan Saphiro,1996). Nilai perubahan digunakan untuk mengatasi adanya stock split, bonus shares, ataupun stock dividend.

\section{Hipotesa}

1. Status perusahaan mempengaruhi economic exposure.

2. Kewajiban bersih valuta asing mempengaruhi economic exposure.

3. Prosentase ekspor terhadap total penjualan mempengaruhi economic exposure. 
4. Perusahaan yang mengimpor bahan baku atau bahan pembantu mempengaruhi economic exposure.

5. Perusahaan melakukan hedging atas fluktuasi kurs mempengaruhi economic exposure.

6. Kelima faktor tersebut mempengaruhi economic exposure.

\section{METODOLOGI}

\section{Metode Pemilihan Sampel}

Kriteria yang digunakan dalam pemilihan sampel, yaitu sampel diambil dari data yang tersedia pada Indonesian Capital Market Directory tahun 2003, sampel yang diambil merupakan perusahaan-perusahaan yang tercatat di Bursa Efek Indonesia sebelum tahun 1999, karena penulis meneliti untuk tahun pengamatan 1999 - 2003, perusahaan yang diteliti tidak melakukan emisi saham baru pada periode 1999-2003 (karena periode ini perekonomian mulai normal kembali pasca krisis moneter, dan sebelum pemilu tahun 2004).

\section{Metode Pengumpulan Data}

Data yang dikumpulkan dalam penulisan tesis ini adalah data sekunder. Indonesian Capital Market Directory tahun 2003, catatan laporan tahunan perusahaan-perusahaan yang menjadi sampel dalam penulisan ini diperoleh dari Bursa Efek Indonesia, dan Statistik Ekonomi dan Keuangan Indonesia yang dikeluarkan oleh Bank Indonesia tahun 1999 hingga tahun 2003. Sedangkan data sekunder lainnya diperoleh melalui internet. Selain itu, data sekunder juga dapat diperoleh dari berbagai bahan-bahan tertulis, baik berupa literature-literatur ilmiah yang digunakan sebagai pondasi teoritis, maupun dari majalah, sutra kabar, laporan penelitian, jurnal ilmiah, serta tulisan-tulisan lainnya yang menunjang penulisan tesis ini.

\section{Metode Analisis Data}

Nilai perubahan digunakan untuk mengatasi adanya stock split, bonus shares, ataupun stock dividend. Model regresi yang digunakan sebagai berikut :

Keterangan :

$$
\text { Yit }=\mathbf{a}+\mathbf{b X i t}+\mathbf{\varepsilon t}
$$

Yit $=$ Perubahan Harga Saham Individu i pada Bulan $\mathrm{t}$

$\mathrm{a}=$ Intersept

bit $\quad=$ Koefisien Economic Exposure

$\varepsilon \quad=\quad$ Perubahan Indeks Harga Saham Gabungan pada Bulan $\mathrm{t}$

Pengujian untuk menentukan adanya pengaruh antara variabel-variabel independen, terhadap variabel dependen pada perusahaan manufaktur dilakukan dengan menggunakan analisa multivariate dengan model sebagai berikut:

$$
B 1 i=a+b 1 \times 1 i+b 2 \times 2 i+b 3 \times 3 i+b 4 \times 4 i+b 5 \times 5 i
$$

Dimana :

$$
\begin{array}{ll}
\text { B1i } & =\text { Economic Exposure } \\
\mathrm{a} & =\text { Intersept } \\
\mathrm{X} 1 \mathrm{i} & =\text { Status Perusahaan }
\end{array}
$$




\begin{tabular}{ll}
\hline X2i & Kewajiban Bersih Valuta Asing \\
X3i & $=$ Prosentase Ekspor Terhadap Total Penjualan \\
X4i & $=$ Impor Bahan Baku dan Bahan Pembantu \\
X5i & $=$ Pelaksanaan Hedging atas Fluktuatif Kurs \\
b1b2b3b4b5 & $=$ Koefisien Variabel Independen
\end{tabular}

Pengukuran variabel dilihat dari definisi konseptual dan definisi operasionalnya.

Berdasarkan model di atas, maka variabel dari penelitian ini adalah :

1. Economic Exposure sebagai dependen variable

2. Variabel yang lain (X1 sampai dengan X5) sebagai dependen variable.

Sebelum dilakukan analisa multivariate, terlebih dahulu dilakukan analisa univariate untuk setiap variabel di atas. Di dalam melakukan analisa univariate variabel-variabel yang mempengaruhi economic exposure digunakan uji-t. Uji-t di sini digunakan untuk menganalisis kelima faktor yang mempengaruhi economic exposure secara parsial. Sedangkan untuk menganalisis kelima faktor secara menyeluruh terhadap economic exposure, digunakan uji-F.

\section{HASIL DAN PEMBAHASAN}

Pengujian Parsial Faktor-Faktor yang Mempengaruhi Economic Exposure

Berdasarkan tabel di bawah ini, faktor yang paling besar pengaruhnya terhadap economic exposure hanya terjadi pada tahun 2000, yaitu faktor kewajiban bersih valuta asing. Hasil uji t terhadap faktor ini adalah t-hitungnya memiliki nilai yang lebih besar dari nilai t-tabelnya, yaitu sebesar 2,350 >1,692, sehingga $\mathrm{Ho} 2$ ditolak dan $\mathrm{Ha} 2$ diterima. Faktor ini juga memiliki nilai signifikan yang lebih kecil dari 0,05 , yaitu 0,025 ,sehingga dapat dikatakankewajiban bersih valuta asing berpengaruh signifikan terhadap economic exposure.

Tabel 1. Pengujian Parsial Faktor-Faktor yang Mempengaruhi Economic Exposure

\begin{tabular}{cccccc}
\hline & $\mathbf{1 9 9 9}$ & $\mathbf{2 0 0 0}$ & $\mathbf{2 0 0 1}$ & $\mathbf{2 0 0 2}$ & $\mathbf{2 0 0 3}$ \\
\hline $\mathbf{X 1}$ & $\mathrm{t}=1,828$ & $\mathrm{t}=-0,005$ & $\mathrm{t}=0,439$ & $\mathrm{t}=-0,202$ & $\mathrm{t}=0,206$ \\
& $(1,692)$ & $(1,692)$ & $(1,692)$ & $(1,692)$ & $(1,692)$ \\
& $\mathrm{Sig}=0,077$ & $\mathrm{Sig}=0,996$ & $\mathrm{Sig}=0,664$ & $\mathrm{Sig}=0,841$ & $\mathrm{Sig}=0,838$ \\
\hline $\mathbf{X 2}$ & $\mathrm{t}=0,959$ & $\mathrm{t}=2,350$ & $\mathrm{t}=0,458$ & $\mathrm{t}=0,632$ & $\mathrm{t}=-1,389$ \\
& $(1,692)$ & $(1,692)$ & $(1,692)$ & $(1,692)$ & $(1,692)$ \\
& $\mathrm{Sig}=0,344$ & $\mathrm{Sig}=0,025$ & $\mathrm{Sig}=0,650$ & $\mathrm{Sig}=0,532$ & $\mathrm{Sig}=0,174$ \\
\hline $\mathbf{X 3}$ & $\mathrm{t}=0,154$ & $\mathrm{t}=-0,315$ & $\mathrm{t}=-0,610$ & $\mathrm{t}=1,901$ & $\mathrm{t}=-0,114$ \\
& $(1,692)$ & $(1,692)$ & $(1,692)$ & $(1,692)$ & $(1,692)$ \\
& $\mathrm{Sig}=0,878$ & $\mathrm{Sig}=0,755$ & $\mathrm{Sig}=0,546$ & $\mathrm{Sig}=0,066$ & $\mathrm{Sig}=0,910$ \\
\hline $\mathbf{X 4}$ & $\mathrm{t}=-0,186$ & $\mathrm{t}=0,604$ & $\mathrm{t}=0,367$ & $\mathrm{t}=-1,498$ & $\mathrm{t}=-1,451$ \\
& $(1,692)$ & $(1,692)$ & $(1,692)$ & $(1,692)$ & $(1,692)$ \\
& $\mathrm{Sig}=0,854$ & $\mathrm{Sig}=0,550$ & $\mathrm{Sig}=0,716$ & $\mathrm{Sig}=0,144$ & $\mathrm{Sig}=0,157$ \\
\hline $\mathbf{X 5}$ & $\mathrm{t}=0,683$ & $\mathrm{t}=0,692$ & $\mathrm{t}=0,692$ & $\mathrm{t}=1,139$ & $\mathrm{t}=1,401$ \\
& $(1,692)$ & $(1,692)$ & $(1,692)$ & $(1,692)$ & $(1,692)$ \\
& $\mathrm{Sig}=1,692$ & $\mathrm{Sig}=0,494$ & $\mathrm{Sig}=0,494$ & $\mathrm{Sig}=0,255$ & $\mathrm{Sig}=0,171$ \\
\hline
\end{tabular}


Pengujian ini dilakukan per tahun, agar dapat mengetahui perubahan signifikansi faktor-faktor penyebab tersebut untuk menjawab permasalahan no.1, serta mengetahui faktor yang dominan yang mempengaruhi economic exposure per tahun untuk menjawab permasalahan no. 2 .

\section{Perhitungan Koefisien Economic Exposure}

Koefisien economic exposure di sini digunakan sebagai variabel dependent dalam analisis multi regresi. Tabel berikut ini merupakan hasil akhir dari olahan regresi yang dilakukan :

Tabel 2. Koefisien Economic Exposure Pada Industri Manufaktur

\begin{tabular}{|c|c|c|c|c|c|}
\hline No. & $\begin{array}{c}\text { Tahun } \\
1999\end{array}$ & $\begin{array}{c}\text { Tahun } \\
2000\end{array}$ & $\begin{array}{l}\text { Tahun } \\
2001\end{array}$ & $\begin{array}{c}\text { Tahun } \\
2002\end{array}$ & $\begin{array}{c}\text { Tahun } \\
2003\end{array}$ \\
\hline 1. & 0,071 & 0,520 & $-0,006$ & 0,043 & 0 \\
\hline 2. & $-0,050$ & $-2,399$ & 0,099 & 0 & 2,139 \\
\hline 3. & $-0,100$ & 0,036 & $-0,103$ & $-0,101$ & 0,650 \\
\hline 4. & $-0,203$ & 0,990 & $-0,053$ & 0,088 & 0,357 \\
\hline 5. & $-0,007$ & 0,068 & 0 & 0 & 0,011 \\
\hline 6. & 0,002 & 0,007 & 0,001 & 0,008 & $-0,006$ \\
\hline 7. & $-0,009$ & 0,030 & $-0,009$ & 0,020 & $-0,063$ \\
\hline 8. & $-0,07$ & 0,404 & 0,159 & $-0,312$ & $-0,291$ \\
\hline 9. & $-0,040$ & 0,020 & 0,001 & 0,003 & 0,008 \\
\hline 10. & $-0,080$ & 0,043 & $-0,003$ & 0 & 0,023 \\
\hline 11. & $-0,018$ & 0,071 & 0 & $-0,003$ & 0,046 \\
\hline 12. & $-0,001$ & 0,007 & $-0,003$ & 0 & 0,010 \\
\hline 13. & $-0,290$ & 0,004 & 0,004 & $-0,015$ & 0,084 \\
\hline 14. & 0,007 & 0,118 & $-0,007$ & $-0,067$ & 0,100 \\
\hline 15. & $-0,011$ & 0,123 & $-0,004$ & $-0,032$ & 0,004 \\
\hline 16. & $-0,007$ & $-0,022$ & 0 & $-0,002$ & $-0,008$ \\
\hline 17. & $-0,022$ & 0,008 & $-0,023$ & $-0,002$ & $-0,159$ \\
\hline 18. & 0,004 & 0,003 & 0,003 & 0,042 & 0,023 \\
\hline 19. & $-0,690$ & $-0,099$ & $-0,020$ & $-0,002$ & 0,124 \\
\hline 20. & $-0,371$ & $-1,090$ & $-0,016$ & $-0,400$ & 0,106 \\
\hline 21. & $-0,003$ & 0,071 & $-0,004$ & $-0,003$ & 0,004 \\
\hline 22. & $-0,003$ & $-0,012$ & 0,003 & 0 & $-0,016$ \\
\hline 23. & 0,012 & 0,003 & 0 & 0,002 & $-0,003$ \\
\hline 24. & $-0,003$ & $-0,030$ & 0,007 & $-0,031$ & $-0,019$ \\
\hline 25. & 0,002 & 0,022 & 0,002 & 0,013 & 0,023 \\
\hline 26. & 0 & 0,012 & 0 & 0 & 0,017 \\
\hline 27. & $-0,023$ & $-0,010$ & 0,006 & $-0,014$ & 0,067 \\
\hline 28. & $-0,040$ & $-0,009$ & 0,001 & 0,005 & $-0,001$ \\
\hline 29. & $-0,006$ & 0,088 & $-0,001$ & $-0,015$ & 0 \\
\hline 30. & $-0,051$ & $-0,084$ & $-0,003$ & 0,010 & 0,039 \\
\hline 31. & $-0,007$ & 0,003 & $-0,001$ & 0,008 & 0,011 \\
\hline 32. & $-0,104$ & 0,149 & $-0,021$ & 0,140 & 0,002 \\
\hline 33. & $-0,014$ & 0,022 & 0,001 & 0,018 & $-0,032$ \\
\hline 34. & 0,012 & 0,025 & $-0,003$ & 0,028 & 0,009 \\
\hline 35. & 0,100 & 0,026 & $-0,001$ & $-0,006$ & 0,003 \\
\hline 36. & $-0,065$ & 0,021 & $-0,001$ & 0,023 & $-0,031$ \\
\hline 37. & 0,012 & 1,023 & 0,053 & 0,006 & 0 \\
\hline 38. & $-0,176$ & $-0,145$ & $-0,113$ & $-0,211$ & $-0,074$ \\
\hline 39. & 0,001 & 0,080 & $-0,037$ & 0,142 & 0,274 \\
\hline
\end{tabular}

Sumber : Data Olahan. 


\section{Pengujian Simultan Faktor-Faktor yang Mempengaruhi Economic Exposure}

Berdasarkan uraian sebelumnya, kelima faktor tersebut secara simultan diuji dengan nilai BUSD yang merupakan ukuran economic exposurenya.

Tabel 3. Pengujian Simultan Faktor-Faktor yang Mempengaruhi Economic Exposure

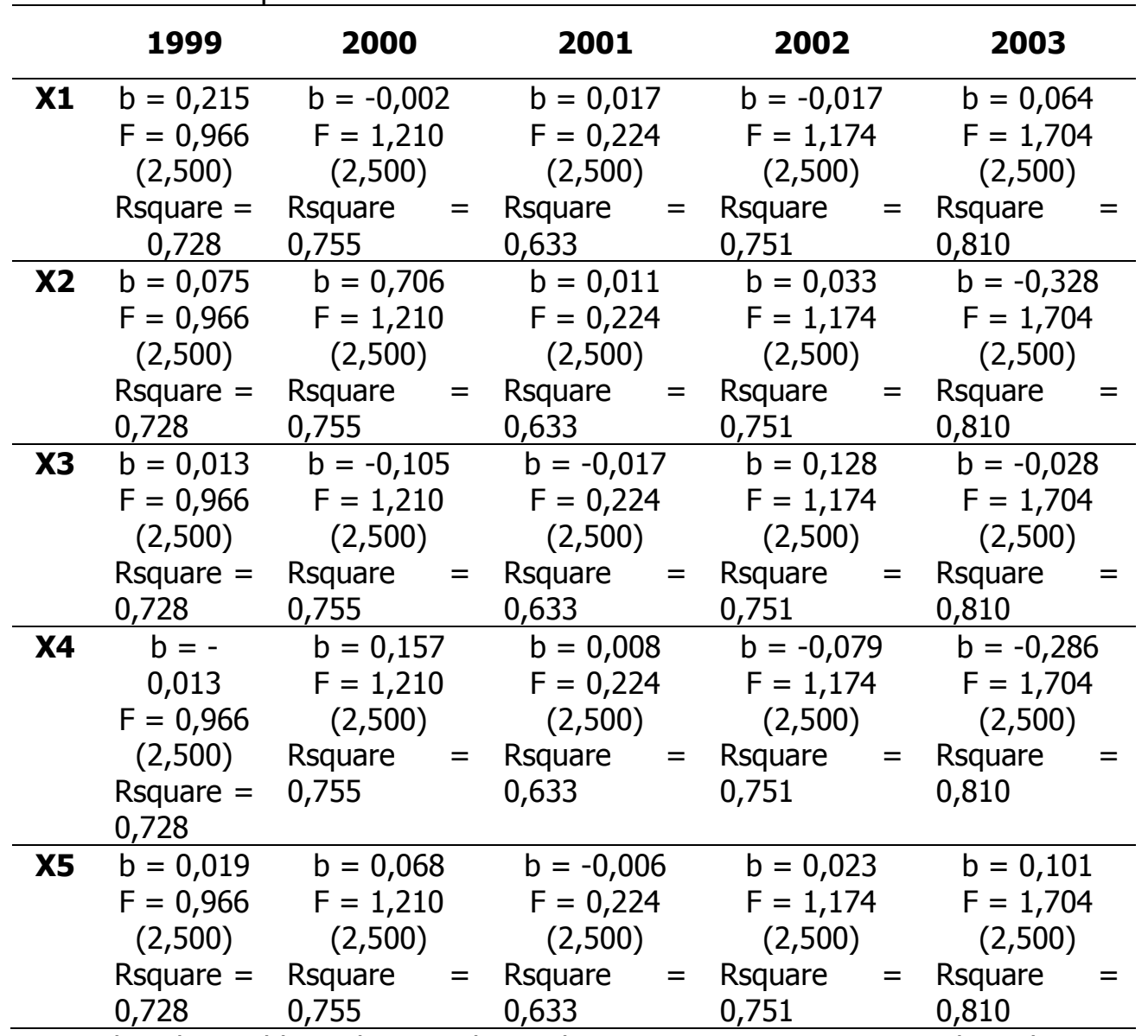

Berdasarkan table 3 di atas, dapat disusun persamaannya per tahun dengan keterangan dari persamaan tersebut, sebagai berikut :

\section{Persamaan Secara Simultan Tahun 1999}

$\beta 1 i=-0,298+0,215 \times 1 i+0,075 \times 2 i+0,013 \times 3 i-0,013 \times 4 i+0,019 \times 5 i$

Berdasarkan persamaan di atas dapat dilihat bahwa status perusahaan, kewajiban bersih valuta asing, prosentase ekspor terhadap total penjualan dan 
pelaksanaan hedging terhadap fluktuasi kurs memiliki arah positif, yang berarti nilai harga saham yang merupakan cerminan dari arus kas perusahaan akan naik searah dengan penguatan niali Rupiah terhadap USD. Sedangkan untuk impor bahan baku atau bahan pembantu memiliki arah negatif, yang berarti bahwa jika Rupiah mengalami penguatan maka arus kas perusahaan akan mengalami penurunan sesuai dengan penurunan harga saham yang merupakan pencerminan arus kas perusahaan.

Berdasarkan nilai F-hitung, maka dapat disimpulkan bahwa Ho6 diterima dan Ha6 ditolak, karena nilai F-hitung < F-tabel, yaitu 0,966 < 2,500 pada taraf signifikansi 0,05.

Secara simultan analisis pada tahun 1999 atas kelima faktor tersebut tidak mempengaruhi economic exposure. Hal ini dapat dilihat dari nilai Rsquarenya yang hanya $62 \%$ mempengaruhi economic exposure, sedangkan $38 \%$ lainnya dipengaruhi oleh faktor lain di luar dari faktor yang diteliti.

\section{Persamaan Secara Simultan Tahun 2000}

$\beta 1 i=-0,517-0,002 \times 1 i+0,706 \times 2 i-0,105 \times 3 i+0,157 \times 4 i+0,068 \times 5 i$

Berdasarkan persamaan di atas dapat dilihat bahwa kewajiban bersih valuta asing, impor bahan baku atau bahan pembantu dan pelaksanaan hedging atas fluktuasi kurs memiliki arah positif, yang berarti nilai harga saham yang merupakan cerminan dari arus kas perusahaan akan naik searah dengan penguatan niali Rupiah terhadap USD. Sedangkan untuk status perusahaan dan prosentase ekspor terhadap total penjualan memiliki arah negatif, yang berarti bahwa jika Rupiah mengalami penguatan maka arus kas perusahaan akan mengalami penurunan sesuai dengan penurunan harga saham yang merupakan pencerminan arus kas perusahaan.

Nilai F-hitung pada tahun 2000 sebesar 1,210. Nilai ini lebih kecil dari $F(0,05,5,33)=2,500$. Maka dapat disimpulkan bahwa Ho6 diterima dan Ha6 ditolak pada taraf signifikansi 0,05, karena nilai F-hitung < F-tabel.

Secara simultan analisis pada tahun 2000 atas kelima faktor tersebut tidak mempengaruhi economic exposure. Hal ini dapat dilihat dari nilai Rsquarenya yang hanya $65,5 \%$ mempengaruhi economic exposure, sedangkan 34,5\% lainnya dipengaruhi oleh faktor lain di luar dari faktor yang diteliti.

\section{Persamaan Secara Simultan Tahun 2001 \\ $\mathrm{B} 3 \mathrm{i}=-0,016+0,017 \mathrm{X} 1 \mathrm{i}+0,011 \times 2 \mathrm{i}-0,017 \mathrm{X} 3 \mathrm{i}+0,008 \times 4 \mathrm{i}-0,006 \times 5 \mathrm{i}$}

Dari persamaan di atas dapat dilihat bahwa prosentase ekspor terhadap total penjualan dan pelaksanaan hedging atas fluktuasi kurs memiliki arah yang negatif. Hal ini mengartikan bahwa jika Rupiah mengalami penguatan atas USD, maka harga saham yang merupakan cerminan dari arus kas perusahaan akan menurun. Untuk status perusahaan, kewajiban bersih vaulta asing dan impor bahan baku memiliki arah negatif yang bermakna bahwa harga saham yang merupakan cerminan dari arus kas perusahaan akan searah pergerakkannya dengan pergerakkan kurs Rupiah terhadap USD. 
Dapat dilihat nilai F-hitung pada tahun 2001 sebesar 0,224. Nilai ini lebih kecil dari F-tabelnya yaitu sebesar 2,500. Maka dapat disimpulkan bahwa Ho6 diterima dan Ha6 ditolak pada taraf signifikansi 0,05, karena nilai F-hitung < Ftabel.

Secara simultan analisis pada tahun 2001 atas kelima faktor tersebut tidak mempengaruhi economic exposure. Hal ini dapat dilihat dari nilai Rsquarenya yang hanya $63 \%$ mempengaruhi economic exposure, sedangkan $37 \%$ lainnya dipengaruhi oleh faktor lain di luar dari faktor yang diteliti.

\section{Persamaan Secara Simultan Tahun 2002}

$\beta 1 i=-0,0557-0,017 \times 1 i+0,033 \times 2 i+0,128 \times 3 i-0,079 \times 4 i+0,023 \times 5 i$

Dari persamaan di atas dapat dilihat bahwa status perusahaan dan impor bahan baku atau bahan pembantu memiliki arah positif, yang berarti nilai harga saham yang merupakan cerminan dari arus kas perusahaan akan naik searah dengan penguatan niali Rupiah terhadap USD. Sedangkan untuk kewajiban bersih valuta asing, prosentase ekspor terhadap total penjualan dan pelaksanaan hedging atas fluktuasi kurs memiliki arah negatif, yang berarti bahwa jika Rupiah mengalami penguatan maka arus kas perusahaan akan mengalami penurunan sesuai dengan penurunan harga saham yang merupakan pencerminan arus kas perusahaan.

Nilai F-hitung pada tahun 2002 lebih kecil dari F-tabelnya yaitu sebesar 1,174 <2,500. Maka dapat disimpulkan bahwa Ho6 diterima dan Ha6 ditolak pada taraf signifikansi 0,05 .

Secara simultan analisis pada tahun 2002 atas kelima faktor tersebut tidak mempengaruhi economic exposure. Hal ini dapat dilihat dari nilai Rsquarenya yang hanya $65,1 \%$ mempengaruhi economic exposure, sedangkan 34,9\% lainnya dipengaruhi oleh faktor lain di luar dari faktor yang diteliti.

\section{Persamaan Secara Simultan Tahun 2003}

$$
\beta 1 i=0,246+0,064 X 1 i-0,328 \times 2 i-0,028 \times 3 i-0,286 \times 4 i+0,101 \times 5 i
$$

Dari persamaan di atas dapat dilihat bahwa status perusahaan dan pelaksanaan hedging atas fluktuasi kurs memiliki arah positif, yang berarti nilai harga saham yang merupakan cerminan dari arus kas perusahaan akan naik searah dengan penguatan niali Rupiah terhadap USD. Sedangkan untuk kewajiban bersih valuta asing, prosentase ekspor terhadap total penjualan dan impor bahan baku atau bahan pembantu memiliki arah negatif, yang berarti bahwa jika Rupiah mengalami penguatan maka arus kas perusahaan akan mengalami penurunan sesuai dengan penurunan harga saham yang merupakan pencerminan arus kas perusahaan.

Nilai F-hitung pada tahun 2003 lebih kecil dari F-tabelnya yaitu sebesar 1,704 $<2,500$. Maka dapat disimpulkan bahwa Ho6 diterima dan Ha6 ditolak pada taraf signifikansi 0,05 .

Secara simultan analisis pada tahun 2003 atas kelima faktor tersebut tidak mempengaruhi economic exposure. Hal ini dapat dilihat dari nilai Rsquarenya 
yang hanya $61 \%$ mempengaruhi economic exposure, sedangkan $39 \%$ lainnya dipengaruhi oleh faktor lain di luar dari faktor yang diteliti.

Pengujian Asumsi

Asumsi yang mendasari suatu pengujian di dalam regresi linier harus memnuhi asumsi dasar bahwa tidak terdapat autokorelasi antara variabel bebas yang satu dengan yang lainnya. Dalam uji ini diperoleh nilai $D$ tahun $1999=$ 1,615 , tahun 2000 , nilai $D=2,063$, tahun 2001 , nilai $D=2,044$, tahun 2002 , nilai $\mathrm{D}=2,158$ dan tahun 2003, nilai $\mathrm{D}=2,071$ dari tahun 1999 hingga tahun 2003 berada pada daerah antara dU dan $4-\mathrm{dU}$, yaitu 1,79 dan 2,21. Dari hasil ini dapat diperoleh bahwa tidak terdapat autokorelasi. Dalam uji asumsi ini juga tidak terjadi multikolinearitas, hal ini dapat dilihat dari probabilitas yang tidak signifikan dari tahun 1999 sampai dengan tahun 2003.

\section{SIMPULAN DAN REKOMENDASI \\ Simpulan}

Besarnya faktor-faktor yang mempengaruhi economic exposure tiap tahun berbeda-beda. Besarnya nilai faktor-faktor yang mempengaruhi economic exposure dapat dilihat dari R Square. Pada tahun 1999, faktor-faktor yang mempengaruhi economic exposure hanya sebesar $62 \%$, sisanya dipengaruhi oleh faktor lain diluar faktor yang diteliti. Untuk tahun 2000, faktor-faktor yang mempengaruhi economic exposure hanya sebesar $65,5 \%, 34,5 \%$ dipengaruhi oleh faktor lain diluar faktor yang diteliti. Pada tahun 2001, faktor-faktor yang mempengaruhi economic exposure sebesar $63 \%$, sedangkan $37 \%$ dipengaruhi oleh faktor lain diluar faktor yang diteliti. Untuk tahun 2002, faktor-faktor yang mempengaruhi economic exposure hanya sebesar $65,1 \%$, sedangkan sisanya dipengaruhi oleh faktor lain diluar faktor yang diteliti. Dan terakhir pada tahun 2003, faktor-faktor yang mempengaruhi economic exposure hanya sebesar $61 \%$, sedangkan 39\% sisanya dipengaruhi oleh faktor lain diluar faktor yang diteliti.

Faktor yang paling besar pengaruhnya terhadap economic exposure adapt dilihat dari hasil uji parsial. Berdasarkan hasil uji t, hanya pada tahun 2000 terdapat faktor yang secara signifikan mempengaruhi economic exposure, yaitu faktor kewajiban bersih valuta asing. Hasil dari uji t terhadap faktor ini adalah, $\mathrm{t}$ hitungnya memiliki nilai yang lebih besar dari t-tabelnya, yaitu sebesar 2,350 > 1,692, sehingga Ho2 ditolak dan Ha2 diterima. Faktor ini juga memiliki nilai signifikan yang lebih kecil dari 0,05, yaitu 0,025, sehingga adapt dikatankan kewajiban bersih valuta asing berpengaruh signifikan terhadap economic exposure.

\section{Rekomendasi}

Untuk penelitian selanjutnya, penulis sarankan untuk menambah sampel dan tahun penelitian. Selain itu, sebaiknya pada penelitian selanjutnya, obyek penelitian ditentukan berdasarkan komposisi ekspor dan impor yang dilakukan suatu perusahaan, jadi bukan berdasarkan suatu golongan industri tertentu agar faktor-faktor yang mempengaruhi economic exposure tersebut dapat lebih signifikan dan kontribusi yang dihasilkan dapat lebih besar nilainya. 
Kelemahan penelitian ini adalah terbatasnya informasi yang dibutuhkan secara detail karena sumber penelitian merupakan perusahaan-perusahaan yang go public dan listing di Bursa Efek Indonesia, sehingga data dan informasinya juga terbatas hanya yang tersedia di perpustakaan Bursa Efek Indonesia saja.

\section{DAFTAR PUSTAKA}

Abuaf, Niso and Schoess, Stephan. 1988. Foreign-Exchange Exposure Management, New York: Executive Enterprise Publications Co, Inc.

Buckley, Adrian. 1992. Multinational Finance, Second Edition, Prentice Hall International, Englewood Cliffs.

Bank Indonesia. 2003. Statistik Ekonomi dan Keuangan Indonesia. Bank Indonesia Desember 2003.

Eiteman, David K, et al. 1995. Multinational Business Finance, Seventh Edition, Reading, Massachusetts: Addition-Wesley Publishing Company.

Hady, Hamdy. 2001. Keuangan Internasional, Buku II, Penerbit Ghalia Indonesia.

Indonesian Capital Market Directory. 2003. Institution for Economic and Financial Research, 2003.

J. Panglaykim, Martani, Murlita. 1988. Bisnis Internasional, Penerbit Universitas Terbuka.

J. Supranto. 2005. Ekonometri, Buku II, Penerbit Ghalia Indonesia.

Levi, Maurice D. 2001. Keuangan Internasional. Buku II, Yogyakarta: Penerbit Andi.

Madura, Jeff. 2003. International Financial Management. Seventh Edition. Singapore: Info Access Distribution, Pte. Ltd.

Santoso, Singgih. 2004. Mengatasi Berbagai Masalah Statistik Dengan SPSS Versi 11,5. Penerbit PT Elex Media Komputindo,.

Saphiro, Alan. 1996. Multinational Financial Management, New Jersey: Prentice Hall International. 